\title{
Hücre Tipine Özgü Analiz : Arabidopsis thaliana Yapraklarında Floresans ile Aktive Edilmiş Hücrelerin Toplanması Yönteminin Kullanımı
}

\author{
Cell-type specific analysis: The use of fluorescence-activated cell sorting (FACS) in Arabidopsis \\ thaliana leaves
}

\author{
Nihal Gören Sağlam (ORCID ID: 0000-0003-1255-5188) \\ İstanbul Üniversitesi, Fen Fakültesi, Biyoloji Bölümü, Botanik Anabilimdal, Süleymaniye, İstanbul
}

\begin{abstract}
$\ddot{O} z$
Gen aktivitesinin hücreye özgü çözümü özel gelişimsel olayların anlaşılmasında kritik bir rol oynamaktadır. Bunun yanında, genomik seviyede böyle yüksek çözünürlüklü verilerin elde edilmesi spesifik hücrelerin izole edilmesini gerektirdiği için oldukça zordur. Aynı organ ya da dokunun komşu hücrelerinden spesifik hücrelerin izole edilebilmesi için en etkili yöntem FACS (Fluorescence-activated cell sortin$\mathrm{g}=$ =Floresans tarafından aktive edilmiş hücrelerin ayrılması) yöntemidir. İzole edilen hücreler genomik analizler için kullanılabilmektedir. $\mathrm{Bu}$ derlemede GFP (Green flourescent protein=Yeşil floresans protein) ile işaretlenmiş transgenik Arabidopsis thaliana bitkilerinin yapraklarında FACS uygulaması hakkında bilgi verilmiş olacaktır.
\end{abstract}

Anahtar Kelimeler: FACS, GFP, Arabidopsis thaliana, gen aktivitesi

\begin{abstract}
Cell-specific resolution of gene activity is critical to understand specific developmental events. However, such high resolution data have been difficult to obtain at a genomic level because specific types of cell need to be isolated. One of the most efficient method to isolate specific cells from neighboring cells in the same organ or tissue is FACS. The isolated cells can be used for genomic analysis. In this review, it will be given information about FACS in transgenic Arabidopsis thaliana leaves which are labelled with GFP.
\end{abstract}

Keywords: FACS, GFP, Arabidopsis thaliana, gene activity

\section{GİRIŞ}

Bitkiler gibi çok hücreli organizmalar farklı fonksiyonları yerine getirebilmek için son derece özelleşmiş hücrelere sahiptirler. Örneğin yapraklar birçok farklı hücre tipinden oluşmuş kompleks bir organdır. Aynı zamanda büyüyen bir yaprak gelişimin farklı safhalarındaki hücreleri içermektedir (petiyol oluşumu ile başlayıp, genişlemenin durması ve senesense maruz kalma gibi) (Şekil 1). Yaprağı oluşturan hücrelerin, hücre tipine göre farklı gelişimsel aşamalarda olması genomik çalışmaların yapılmasında zorluklar oluşturmaktadır. Elde edilen verilerin analizinde farklı gelişimsel aşamalardaki hücrelerden gelen sinyaller kafa karışıklığına neden olmakta ve hatalı sonuçların oluşma riski artmaktadır. $\mathrm{Bu}$ durumun bertaraf edilebilmesi için hücreye özgü gen anlatımına olanak sağlayacak değişik metodların geliştirilmesi zorunluluğu doğmuştur. Özellikle RNA amplifikasyon tekniklerindeki gelişmeler çok küçük miktarlardaki RNA nın analiz edilmesini mümkün kılmıştır [1]. Bir diğer aşılması gereken problem ise tek hücre analizinin etkili olabilmesi için bitki dokusundan hedef hücrenin kusursuz bir şekilde çıkarılabilmesidir. Bitki hücrelerinin geniş vakuol ve hücre duvarına sahip olması bu işlemi zorlaştırmaktadır. Bunun yanında, son yıllarda yeni tekniklerin geliştirilmesi ile tek hücre seviyesindeki gen anlatımı çalışmaları artmıştır [2]. Hücre tipine özgü analiz yöntemi olarak adlandırılan bu metodlar; 
- Laser tarafından tutulmuş hücrelerin mikrodiseksiyonu $=$ Laser capture microdissection (LCM)

- Çevrilen ribozom afinite saflaştırılması=Translating ribosome affinity purification (TRAP)

- Çekirdeksel izolasyon=Nuclear isolation

- Floresans ile aktive edilmiş hücrelerin toplanması=Fluorescence-activated cell sorting (FACS) dir.

$\mathrm{Bu}$ yöntemlerin özelliklerini gösteren özet bilgiler Tablo 1 de verilmiştir.

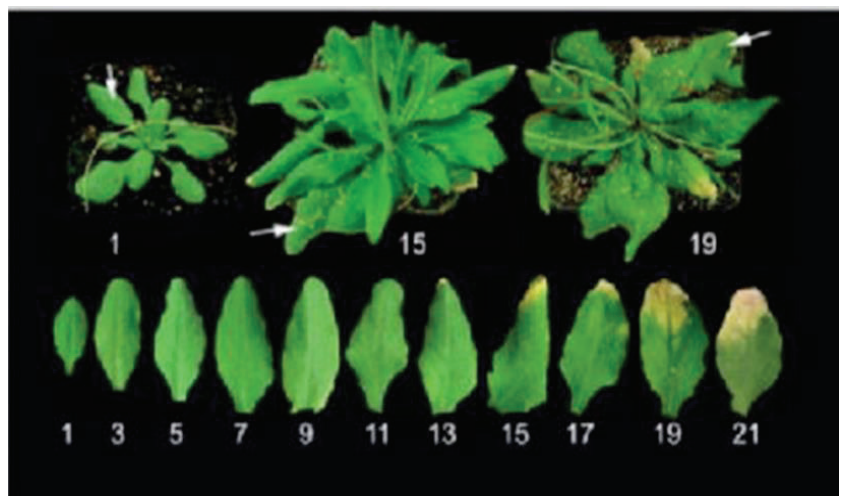

Şekil 1: Farklı gelişimsel aşamalardaki Arabidopsis thaliana bitkisinin 7. yaprağının görünümü (http://www2.warwick.ac.uk/ fac/sci/lifesci/people/1/vbuchanan-wollaston/systems)

\subsection{Floresans tarafından aktive edilmiş hücrelerin ayrilması (Fluorescence-activated cell sorting =FACS)}

Floresans tarafından aktive edilmiş hücrelerin ayrılması (Florescence-activated cell sorting=FACS) karışık bir hücre populasyonunun floresans özelliklerini temel alarak ayrılmasına ve analiz edilmesine izin veren bir çeşit flow sitometri tekniğidir [4]. Aynı organ ya da dokunun komşu hücrelerinden spesifik hücrelerin izole edilebilmesi için en etkili yöntem FACS yöntemidir. Bu metod lazer mikrodiseksiyon (Laser capture microdissection=LCM) yöntemine alternatif olarak geliştirilmiş yüksek verimlilikde transkript analizine izin veren bir yüntemdir. FACS da floresans işaretçinin anlatımının olduğu transgenik hatlar kullanılmaktadir ve LCM ye oranla daha az zaman alan bir yöntemdir. Bitkilerde hücre toplanmasında ki ilk anahtar gelişme hücre gruplarındaki floroforların anlatımının olduğu transgenik bitkilerin elde edilebilirliğinin artmas1dır. Bitkilerde, GFP hatlarının bulunabilirliğinden dolayı, baskın olarak GFP kullanımı olsada herhangi bir florofor da FACS için bitkileri işaretlemede kullanılabilir [5]. Bitki hücrelerinde FACS uygulamasını kolaylaştırmak için ikinci anahtar öğe koruyucu hücre duvarı varlığının üstesinden gelmektir. Bu amaçla protoplast oluşturmak için, bitki köklerindeki hücreleri ayırmada hücre duvarını parçalayıcı hidrolitik enzimler kullanılarak metodlar geliştirilmiştir

Tablo 1: Hücre tipine özgü analiz metodlarının karşılaştırılmalı özeti [3]

\begin{tabular}{|c|c|c|c|c|c|}
\hline Yöntem & $\begin{array}{l}\text { İzole edile- } \\
\text { cek hedef }\end{array}$ & İzolasyon metodu & $\begin{array}{l}\text { Profili çıkarı- } \\
\text { lacak hedef }\end{array}$ & Özellikler & Kisitlamalar \\
\hline $\begin{array}{l}\text { Lazer Mikrodi- } \\
\text { seksiyon }\end{array}$ & $\begin{array}{l}\text { Doku ke- } \\
\text { sitlerinden } \\
\text { hücreler }\end{array}$ & $\begin{array}{l}\text { Histolojik doku kesitlerin- } \\
\text { den lazer yardımı ile hücre- } \\
\text { lerin alınması }\end{array}$ & $\begin{array}{l}\text { Hücrelerin } \\
\text { içindeki tüm } \\
\text { mRNAlar }\end{array}$ & $\begin{array}{l}\text { Hücreler kesitteki görünüm } \\
\text { ve lokasyonlarına göre seçilir, } \\
\text { tek genetik hat gerektirmez }\end{array}$ & $\begin{array}{l}\text { Elde edilen hedef hücrelerin sayısı sınırlı } \\
\text { olduğu için RNA amplifikasyonuna ihti- } \\
\text { yaç duyar, özel cihazlar gereklidir }\end{array}$ \\
\hline $\begin{array}{l}\text { Floresans ile } \\
\text { aktive edilmiş } \\
\text { hücrelerin top- } \\
\text { lanması }\end{array}$ & $\begin{array}{l}\text { Floresans } \\
\text { ile işaretlen- } \\
\text { miş protop- } \\
\text { lastlar }\end{array}$ & $\begin{array}{l}\text { Dokuların parçalanmasını } \\
\text { takiben flow sitometri te- } \\
\text { melli protoplast izolasyonu }\end{array}$ & $\begin{array}{l}\text { Hücrelerin } \\
\text { içindeki tüm } \\
\text { mRNAlar }\end{array}$ & $\begin{array}{l}\text { Anlatımı olmuş floresans pro- } \\
\text { teinler esas alınarak hücrele- } \\
\text { rin toplanması, kimyasal ve } \\
\text { mekanik protoplast izolasyo- } \\
\text { nunu içerir }\end{array}$ & $\begin{array}{l}\text { Protoplast izolasyonu ve hücre toplama } \\
\text { transkripsiyon profilini olumsuz etkiler. } \\
\text { Elde edilen hedef hücrelerin sayısının s1- } \\
\text { nırlı olması nedeniyle RNA amplifikas- } \\
\text { yonuna ihtiyaç duyar, bitkilerin yoğun } \\
\text { genetik manipülasyonuna ihtiyaç duyar, } \\
\text { hücre-spesifik promotörlere ihtiyaç du- } \\
\text { yar }\end{array}$ \\
\hline $\begin{array}{l}\text { Çevrilen ribo- } \\
\text { zom afinite saf- } \\
\text { laştırılması }\end{array}$ & $\begin{array}{l}\text { Afinite-e- } \\
\text { tiketli poli- } \\
\text { zomlar }\end{array}$ & $\begin{array}{l}\text { İlgili mRNAlar ile bir- } \\
\text { likte etiketli poliribozomal } \\
\text { kompleksin immünosaflaş- } \\
\text { tırılması }\end{array}$ & $\begin{array}{l}\text { Çevirisi olmuş } \\
\text { mRNAlar }\end{array}$ & $\begin{array}{l}\text { Çevrilen (translating) mRNA } \\
\text { profili için polizomların hüc- } \\
\text { re-spesifik saflaştırılması, } \\
\text { nispeten hedef mRNAnın } \\
\text { yüksek verimi, nispeten dü- } \\
\text { şük maliyet }\end{array}$ & $\begin{array}{l}\text { Bitkilerin yoğun genetik manipülasyo- } \\
\text { nuna ihtiyaç duyar, hücre-spesifik pro- } \\
\text { motörlere ihtiyaç duyar }\end{array}$ \\
\hline $\begin{array}{l}\text { Çekirdeksel } \\
\text { izolasyon }\end{array}$ & $\begin{array}{l}\text { Floresans } \\
\text { işaretli ya } \\
\text { da afinite-e- } \\
\text { tiketli nuk- } \\
\text { leuslar }\end{array}$ & $\begin{array}{l}\text { Çekirdeksel izolasyon ve } \\
\text { floresans ile aktive edilmiş } \\
\text { toplamaya dayalı zenginleş- } \\
\text { tirme ya da afinite-temelli } \\
\text { saflaştırma }\end{array}$ & $\begin{array}{l}\text { Çekirdeksel } \\
\text { mRNAlar }\end{array}$ & $\begin{array}{l}\text { Hücreye özel olarak işaretli } \\
\text { nukleusların izolasyonu, pro- } \\
\text { toplast izolasyonuna ihtiyaç } \\
\text { duymaz }\end{array}$ & $\begin{array}{l}\text { Sitoplazmik mRNAlar belirlenemez, bit- } \\
\text { kilerin yoğun genetik manipülasyonuna } \\
\text { ihtiyaç duyar, hücre-spesifik promotör- } \\
\text { lere ihtiyaç duyar, nukleusların toplan- } \\
\text { ması için özel ekipmanlar gereklidir. }\end{array}$ \\
\hline
\end{tabular}


[6]. Üçüncü önemli kısım ise genom seviyesinde analiz için, az miktardaki izole edilmiş hücre tiplerinden elde edilen küçük miktardaki RNAnın miktarının artırılmasıdır. Bunun için de RNA miktar artırıcı kitler (amplifikasyon kitleri) bulunmaktadır [4]. Bu derlemede FACS ile ilgili detaylı bilgi GFP (Green flourescent protein) ile işaretlenmiş transgenik Arabidopsis thaliana bitkilerinin yapraklarında FACS uygulaması örneği üzerinden verilecektir.

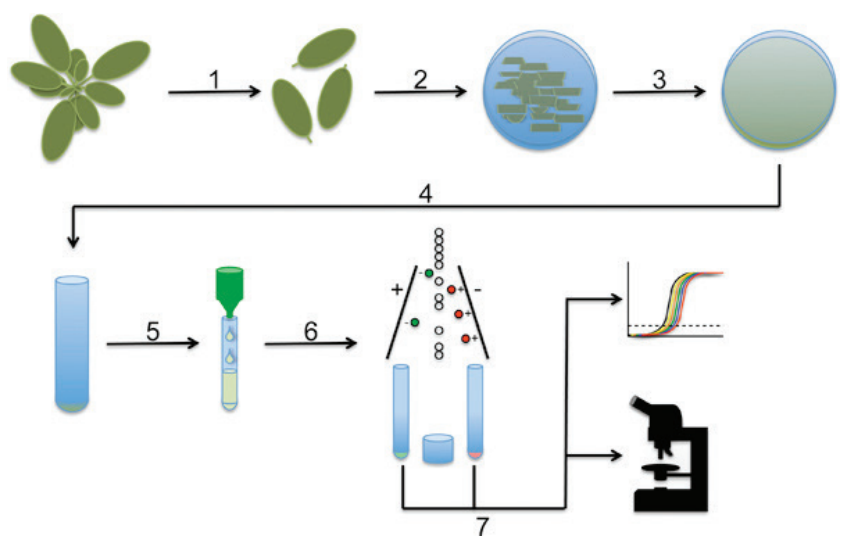

Şekil 2: Arabidopsis yapraklarında hücre tipine özgü analiz yönteminin şematik gösterimi [7]

1. Bir GFP (Green fluorescent protein =Yeşil floresan protein) anlatımı olan Arabidopsis hattından alınan yapraklar kullanılır. Bunun için GFP anlatımı olan transgenik hatların yapraklarından alınan kesitler konfokal mikroskop altında incelenir ve GFP anlatımının yaprağın hangi hücresinde olduğu tespit edilir. Bu inceleme sonucunda seçilen bitkilerin yaprakları hasat edilir.

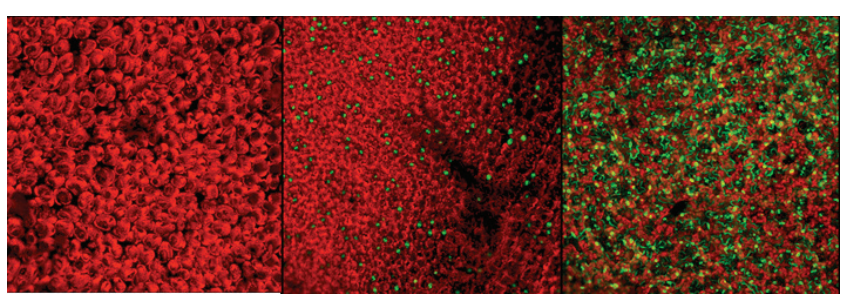

Şekil 3: Konfokal mikroskop altında GFP $(+)$ hücrelerin görünümü [8]

2. Yapraklar $1 \mathrm{~mm}$ olacak şekilde hızlıca kesilir, protoplast izolasyonu yapılacak çözeltiye alınır ve vakum yapılır.

3. Örnekler 3-4 saat çalkalayıcı üzerinde inkübe edilir.

4. Protoplast solusyonu $70 \mu \mathrm{m}$ çapındaki elekten süzülür ve santrifüj edilir.
5. Protoplastlar resuspanse edilir ve $50 \mu \mathrm{m}$ çapındaki filtreden süzülerek toplama tüpüne alınır.

6. GFP (+) ve GFP (-) canlı protoplastlar FACS cihazı yardımı ile ayrılır.

7. Elde edilen protoplastlar qPCR, NGS ve mikroarray teknikleri kullanılarak analiz edilebilirler.

\section{SONUÇ}

FACS, bitki büyümesini ve gelişimini hücresel seviyede çalı̧̧maya olanak sağlayan çok güçlü bir tekniktir. Yapılan ça1ışmalar protoplast izolasyonu ve FACS uygulaması ile genomik çalışmalar için kullanılacak hedef hücrelerin yeterli saflıkta ve miktarda elde edilebileceğini göstermektedir [8]. Ayrıca bu hücreler ile yapılacak genomik analizler tüm bir organı kullanarak yapılan analizlerden daha net sonuçlar elde edilmesine de olanak sağlayacaktır.

\section{KAYNAKÇA}

[1] Hertzberg, M., Sievertzon, M., Aspeborg, H., Nilsson, P., Sandberg, G., \& Lundeberg, J. (2001). cDNA microarray analysis of small plant tissue samples using a cDNA tag target amplification protocol. The Plant Journal, 25(5), 585-591.

[2] Lee, J. Y., Levesque, M., \& Benfey, P. N. (2005). High-throughput RNA isolation technologies. New tools for high-resolution gene expression profiling in plant systems. Plant physiology, 138(2), 585-590.

[3] Wang, Y., \& Jiao, Y. (2011). Advances in plant cell type-specific genome-wide studies of gene expression. Frontiers in Biology, 6(5), 384-389.

[4] Carter, A. D., Bonyadi, R., \& Gifford, M. L. (2013). The use of fluorescence-activated cell sorting in studying plant development and environmental responses. The International journal of developmental biology, 57, 545-552.

[5] Birnbaum, K., Shasha, D. E., Wang, J. Y., Jung, J. W., Lambert, G. M., Galbraith, D. W., \& Benfey, P. N. (2003). A gene expression map of the Arabidopsis root. Science, 302(5652), 1956-1960.

[6] Birnbaum, K., Jung, J. W., Wang, J. Y., Lambert, G. M., Hirst, J. A., Galbraith, D. W., \& Benfey, P. N. (2005). Cell type-specific expression profiling in plants via cell sorting of protoplasts from fluorescent reporter lines. Nature methods, 2(8), 615-619.

[7] Grønlund, J. T., Eyres, A., Kumar, S., Buchanan-Wollaston, V., \& Gifford, M. L. (2012). Cell specific analysis of Arabidopsis leaves using fluorescence activated cell sorting. Journal of visualized experiments: JoVE, (68).

[8] Gören Sağlam, N. (2017). Arabidopsis thaliana (L.) Heynh. yapraklarında GUS ve GFP raportör genleri kullanılarak senesens ile ilişkili genlerin analizi. Trakya University Journal of Natural Sciences, 18(2), 175-183. 